\section{ESTIMATION OF DEMAND AND SUPPLY OF PULPWOOD BY ARTIFICIAL NEURAL NETWORK: \\ A CASE STUDY IN TAMIL NADU}

$S$ Varadha Raj

N Narmadha

T Alagumani

M Chinnaduri

K R Ashok
Sri Lanka Journal of Economic Research Volume 2 (1)

June 2014: 81-88

Sri Lanka Forum of University Economists

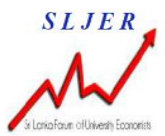

\title{
Abstract
}

The annual demand of paper and paperboard, including newsprint is at 11.15 Million Tones (MT) in India. The per-capita consumption is nearly $10.5 \mathrm{~kg}$. The growth in the number of paper mills was from 17 units in 1950 to 759 units in 2010 with the production of 10.11 MT per annum. In Tamil Nadu, Tamil Nadu News prints and Papers Limited (TNPL) and Seshasayee Paper and Board Limited (SPB) are the major pulpwood based paper industries, which require 0.8 to 0.9 MT of pulpwood per year, whereas the availability of pulpwood is nearly 0.6 to 0.65 MT per year. This short supply will affect their performance in the market. Hence, this paper is to assess the factual demand and supply gap of industrial raw materials with different forecasting methods viz., trend analysis, moving average, single exponential smoothing model and Artificial Neural Network (ANN). Based on forecast accuracy, ANN is observed as a reliable method which measures that the demand-supply gap of raw materials will be 0.01 MT and 0.24 MT in 2015 and 2020 respectively. In order to bridge the gap, industries must additionally produce raw materials by promoting resourceful captive plantation and the farm forestry area with profitable business model.

Key Words: Paper industry, Demand supply gap, Pulpwood, Forecasted value and Artificial Neural Network

JEL Codes : $C 13, C 80, L 60, L 66$

\section{S Varadha-Raj}

Department of Agricultural Economics, TNAU, Coimbatore, Tamil Nadu, India Telephone: +919865021569, email: varadharajs@

\section{N Narmadha}

Vanavarayar Institute of Agriculture, Pollachi, Tamil Nadu, India Telephone: +919095043072, email: varadharajs@ rediffmail.com

\section{T Alagumani}

Department of Agricultural Economics, TNAU, Coimbatore, Tamil Nadu, India Telephone: +919942390078, email: talagumani@yahoo.co.in

\section{Chinnaduri}


Centre for Agricultural and Rural Development Studies, TNAU, Coimbatore, Tamil Nadu, India

Telephone: +919443080887, email: $\underline{\text { mcdurai@ hotmail.com }}$

\section{K R Ashok}

Department of Agricultural Economics, TNAU, Coimbatore, Tamil Nadu, India Telephone: +919443001852, email: ashok10tnau@yahoo.com

\section{INTRODUCTION}

The current global paper and paperboard demand is 402 million tonnes (MT) per annum and there are more than 7,745 mills producing 192 MT of pulp. The paper demand has nearly doubled in 20 years from 242.79 MT in 1990 to 402 MT in 2011-12. Paper production is projected at $521 \mathrm{MT}$ per annum in 2021 (Kulkarni, 2008). Asia produces nearly 177 MT (44\%) and the rest of the world produces 225 MT (56\%). The per capita consumption of paper in India was only $9.3 \mathrm{~kg}$ in 2011 as against $42 \mathrm{~kg}$ in China, $22 \mathrm{~kg}$ in Indonesia, $25 \mathrm{~kg}$ in Malaysia, $250 \mathrm{~kg}$ in Japan and $325 \mathrm{~kg}$ in the USA. The demand of paper is strongly linked with GDP growth (Mohammad Aslam Khan, 2012). In 2012, there were nearly 800 paper mills in India, out of which 26 were wood-based and face challenges of short supply. The annual pulp production of 1.9 MT consumes 6.8 MT of raw wood, of which nearly 20 per cent are supplied from natural forests through government sources, and the remaining 80 per cent is supplied from Trees Outside Forest (TOF) area, especially from farmers' lands (Kulkarni, 2012).

The growth of pulpwood based industries was 5 per cent per annum in 1990s and 10 per cent in 2010. Many paper industries are not able to gain access to land where they can establish plantations and get the raw materials from natural forests. Eucalyptus, casuarina and Melia dubia are the important tree species used as raw material for the manufacture of pulp and paper products in Southern India (Prasad et al., 2010). One tonne of paper production requires approximately 4.5 tonnes of freshly harvested pulpwood. The pulpwood demand for pulpwood based industries had increased to 21.92 million $\mathrm{m}^{3}$ in 2010 from 8.76 million $\mathrm{m}^{3}$ in 2000. This will increase to 34.67 million $\mathrm{m}^{3}$ in 2015 and 45.80 million $\mathrm{m}^{3}$ in 2020 (FAO Report, 2009).

In Tamil Nadu, Tamil Nadu Newsprint and Papers Ltd (TNPL) at Karur and Seshasayee Paper Board (SPB) at Erode are major pulpwood based paper industries that use predominantly hardwoods like eucalyptus, casuarina and miscellaneous wood as raw material. Due to the stringent forest policy, low productivity of forest cover, higher demand for pulpwood and higher installation capacity of industries, the supply (0.5 MT to $0.6 \mathrm{MT}$ ) is not keeping up with the spiraling demand for raw material (8 lakh tonnes).

There is a huge demand for pulpwood from the paper industries and inconsistent supply of raw materials from the natural forest, together with low productivity and stringent forests acts and policies paves the way for generating adequate raw materials from the 
Tree outside Forest (TOF) area especially from farmer's fields. The agricultural area is continuously shrinking over the decades due to several factors. Prime factors like climatic change and labor problems in agriculture, force farmers to make the technological and economic shift to pulpwood based agroforestry models to increase net farm income. The pulpwood based agro forestry models appear to be the only solution to meet the current spiraling requirement of raw material requirement. Scientific information on demand, supply and the gap for pulpwood would benefit all the stake holders in their decision making. This study aims at assessing the demand and supply of pulpwood to formulate strategic plans.

\section{Review of Literature}

Demand refers to wants for specific products that are backed up by an ability and willingness to buy them (Philip Kotler and Kevin Lane Keller, 2005). Subba Reddy et al. (2008) defined demand as a schedule that shows the amounts of a product or service the consumers are willing and able to purchase at each price in a set of possible prices during some specified time in a specified market. Acharya and Agarwal (2012) referred to demand as the quantity of a product or service which the buyers are likely to purchase at different prices in a given market at a given time. In this study, demand refers to the quantity of pulpwood required from the paper industries at a given price and time.

According to Katila and Paivo Rithinen (1990), the supply of primary forest products would be conditioned by actual forest cover, investment in forest management, the input of labor and the market prices of the products under consideration. The supply of secondary products would be governed by the availability of processing chemicals, machines, skilled labor, capital investment, market prices and their management. Supply is the quantities of product that will be offered for sale at different prices at a given time and in a given market (Acharya and Agarwal, 2012). In this study, supply refers to the quantity of pulpwood sold to the paper industries for a specific price and time by farmers, forest department and in open markets. The main source of supply is from forest department, industries owned captive plantations and contract farmers of the industry and other farm forestry plantations.

Ivaneevich et al. (1991) stated that forecasting is the process of using past and current information to predict future events. According to Arunkumar and Rachana Sharma (2000), forecasting refers to the statistical analysis of the past and current movements in the given time series so as to obtain clues about the future of those movements. Sakthimurugan (2004) defined that forecasting is a systematic attempt to probe the future by inference from the known facts. Time series analysis consists of breaking down past time series into four components (trend, cycle, seasonal and erratic) and projecting these components into the future. Saxena (2009) stated that forecasting is a technique to plan the future activities and is based on a past data, systematically 
arranged in a predetermined way to prepare estimates for the future. He also defined forecasting as a quantitative technique to project the demand for a product or service.

\section{METHODOLOGY}

The list of tree growing farmers at selected villages was obtained from TNPL. The data from the sample farms were collected with the help of a well-structured and pre-tested interview schedule through personal interview. The demand, supply of raw materials, installing capacity, area of captive plantation, paper productions from two industries were collected for a period of 10 years from 2003 to 2012. The quantity of an input demanded is a function of the price of the input, price of other inputs, and price of output for a profit maximizing industry. The quantity of pulpwood supply is a function of output price, input prices and technology.

\section{a) Compound Growth Rate Analysis (CGR)}

In order to estimate the demand and supply of pulpwood in Tamil Nadu, compound growth rate was computed using the method of ordinary least squares by fitting the semi - logarithmic function (equation 1).

$$
Y_{t}=\mathbf{a b}^{\mathbf{t}}
$$

Where,

$\mathrm{Y}_{\mathrm{t}}=$ dependent variable (demand $/$ supply), $\mathrm{t}=$ time element which takes the value $1,2,3, \ldots \ldots \mathrm{n}$

$\mathrm{a}=$ intercept term, $\mathrm{b}=(1+\mathrm{r})$ and $\mathrm{r}$ is the compound growth rate and $\mathrm{e}_{\mathrm{t}}=$ error term. In the logarithmic form the function is expressed in equation 2.

$$
\log Y_{t}=\log a+t \log b
$$

$\log \mathrm{a}$ and $\log \mathrm{b}$ were obtained using ordinary least squares procedures and the $\mathrm{R}^{2}$ was computed to test the goodness of fit. (Antilog b - 1) x 100 gave the per cent growth rate. The future value of pulpwood was estimated as in equation 3 .

$$
\text { Future year }=\text { Present year } *(1+r)^{n}
$$

Where, $r=$ Growth rate, $n=$ Number of Years

\section{b) Trend Analysis}

Trend analysis fits a particular type of trend line or curve to a time series data. Minitab also displays the fitted trend equation and three measures to help in determining the accuracy of the fitted values by Mean Absolute Percentage Error (MAPE). The equations adopted for this purpose are specified in equations 4-6. 


$$
\begin{aligned}
& \text { Linear trend } \\
& \text { Quadratic trend }
\end{aligned}
$$$$
\text { Exponential growth trend : } Y_{t}=\text { aebt }
$$

where, $\mathrm{Y}_{\mathrm{t}}=$ trend values at time $\mathrm{t}, \mathrm{a}=$ intercept parameter, $\mathrm{b}$ and $\mathrm{c}=$ slope parameters, $\mathrm{e}=$ exponential term and $\mathrm{t}=$ time period. After subjecting the original data to time series analysis in MINITAB package variations in auctioned values is notified. By the option of regression form, seasonal trend is computed and compared based on the goodness of fit by $\mathrm{R}^{2}$ and standard error. From the best performing trend curve demand and supply were forecasted up to 2020 and evaluated for accuracy. The performances of these approaches were justified by considering their error measurement, Mean Absolute Percentage Error (MAPE).

\section{c) Artificial Neural Network}

The neural architecture consists of three or more layers, i.e. input layer, output layer and hidden layer shown in Figure.1. The functional form of this network is represented in equation 7 .

$$
Y_{j}=f\left(w_{i j}, X_{i j}\right)
$$

where $\mathrm{Y}_{\mathrm{j}}$ is the output of node $\mathrm{j}, \mathrm{f}\left(w_{i j}, X_{i j}\right)$ is the transfer function, $\mathrm{W}_{\mathrm{ij}}$ the connection weight between node $\mathrm{j}$ and node $\mathrm{i}$ in the lower layer and $\mathrm{X}_{\mathrm{ij}}$ is the input signal from the node $\mathrm{i}$ in the lower layer to node $\mathrm{j}$. Alyuda forecaster XL 2.4 was used for development of ANN models based on relationship of input variables and output variables.

The annual compound growth rate (CGR) of pulpwood demand was 15.41 per cent and future demand of pulpwood would be 1.18 MT in 2015-16 and 2.42 MT in 2020-21. The future pulpwood supply would be 1.12 MT in 2015-16 and 2.29 MT in 2020-21. Quadratic model was the best fit among CGR, linear and exponential models, because it had the lower MAPE value. Based on the quadratic model, the estimated demand is 1.19 MT and supply is 1.05 MT and the supply- demand gap is 0.15 MT in 2015-16. The estimated demand of pulpwood in 2020 -21 is 2.01 MT and supply is 1.68 MT and supply - demand gap is and $0.33 \mathrm{MT}$. 


\section{Figure 1: The Architecture of ANN}

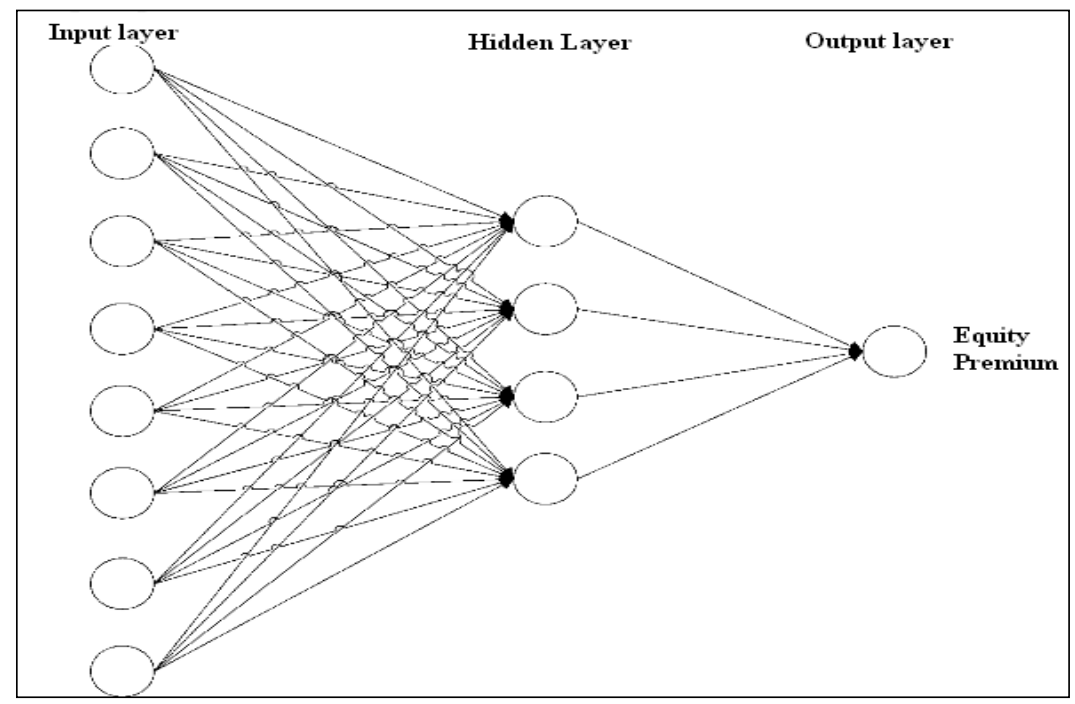

Figure 2: Forecasted Demand and Su pply of Pulpwood by ANN

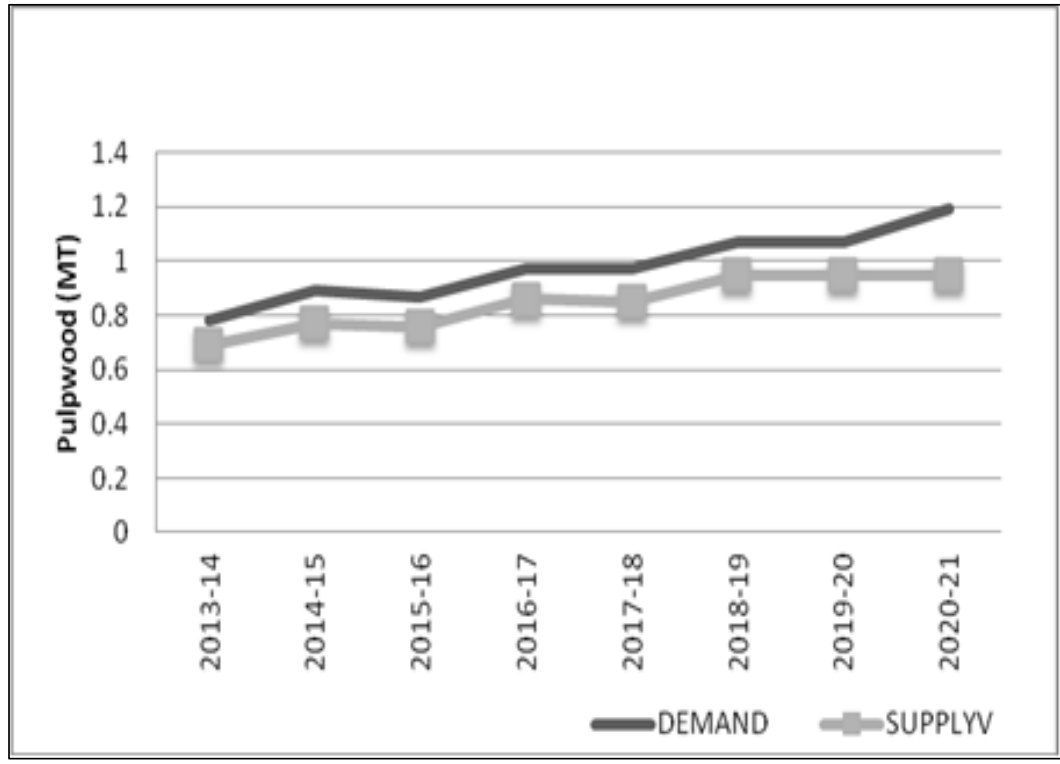




\section{RESULTS}

Table.1: Forecasted Demand and Supply of Pulpwood for Paper Industries in Tamil Nadu

(MT)

\begin{tabular}{|r|r|r|r|r|r|r|r|r|r|r|r|r|r|r|r|r|}
\hline \multirow{2}{*}{ Year } & \multicolumn{4}{|c|}{ CGR } & \multicolumn{3}{|c|}{ Linear } & \multicolumn{3}{|c|}{ Quadratic } & \multicolumn{2}{|c|}{ Exponential } & \multicolumn{3}{|c|}{ ANN } \\
\cline { 2 - 19 } & D & S & G & D & S & G & D & S & G & D & S & G & D & S & G \\
\hline 2013 & 0. & 0. & 0. & 0. & 0. & 0. & 0. & 0. & 0. & 0. & 0. & 0. & 0. & 0. & 0. \\
-14 & 89 & 84 & 05 & 83 & 77 & 06 & 94 & 84 & 10 & 94 & 88 & 06 & 78 & 69 & 09 \\
\hline 2014 & 1. & 0. & 0. & 0. & 0. & 0. & 1. & 0. & 0. & 1. & 1. & 0. & 0. & 0. & 0. \\
-15 & 03 & 97 & 06 & 89 & 83 & 07 & 06 & 94 & 12 & 08 & 02 & 06 & 89 & 77 & 12 \\
\hline 2015 & 1. & 1. & 0. & 0. & 0. & 0. & 1. & 1. & 0. & 1. & 1. & 0. & 0. & 0. & 0. \\
-16 & 18 & 12 & 07 & 96 & 89 & 07 & 19 & 05 & 15 & 25 & 18 & 07 & 87 & 76 & 11 \\
\hline 2016 & 1. & 1. & 0. & 1. & 0. & 0. & 1. & 1. & 0. & 1. & 1. & 0. & 0. & 0. & 0. \\
-17 & 37 & 29 & 08 & 03 & 95 & 08 & 34 & 16 & 18 & 44 & 36 & 09 & 97 & 86 & 11 \\
\hline 2017 & 1. & 1. & 0. & 1. & 1. & 0. & 1. & 1. & 0. & 1. & 1. & 0. & 0. & 0. & 0. \\
-18 & 58 & 49 & 09 & 09 & 01 & 08 & 49 & 28 & 21 & 67 & 57 & 10 & 97 & 85 & 11 \\
\hline 2018 & 1. & 1. & 0. & 1. & 1. & 0. & 1. & 1. & 0. & 1. & 1. & 0. & 1. & 0. & 0. \\
-19 & 82 & 72 & 10 & 16 & 07 & 09 & 65 & 41 & 25 & 92 & 81 & 11 & 07 & 95 & 12 \\
\hline 2019 & 2. & 1. & 0. & 1. & 1. & 0. & 1. & 1. & 0. & 2. & 2. & 0. & 1. & 0. & 0. \\
-20 & 10 & 98 & 12 & 22 & 13 & 09 & 83 & 54 & 28 & 22 & 09 & 13 & 07 & 95 & 12 \\
\hline 2020 & 2. & 2. & 0. & 1. & 1. & 0. & 2. & 1. & 0. & 2. & 2. & 0. & 1. & 0. & 0. \\
-21 & 42 & 29 & 13 & 29 & 19 & 10 & 01 & 68 & 33 & 56 & 41 & 15 & 19 & 95 & 24 \\
\hline
\end{tabular}

D-Demand; S-Supply; G-Demand and Supply Gap

Based on the outcome of the Artificial Neural Network (ANN) model, forecast value of pulpwood demand is 0.87 MT in 2015-16 and 1.19 MT in 2020-21. The supply of pulpwood will be 0.76 MT and 0.95 MT in 2015-16 and 2020-21 respectively. The demand and supply gap of raw materials would be 0.11 MT and 0.24 MT in 2015-16 and 2020-21. Among all above methods, ANN was the best method, because it had higher $\mathrm{R}^{2}$ and the lowest error than the quadratic model.

\section{CONCLUSION AND POLICY RECOMMENDATION}

The forecasted demand and supply gap of pulpwood for pulpwood based paper industries during 2015-16 and 2020-21 would be nearly 0.24- 0.33 MT. This short supply will affect the performance of paper industries and paper production in the country. In order to bridge the gap, the industries must additionally produce the raw material by promoting the captive plantations and the farm forestry area with eucalyptus and casuarina in TOF of $1000-1200$ hectares per year. Tree crops of 3 to 4 year rotation are to be raised to meet out the demand and supply gap of pulpwood. 


\section{REFERENCES}

Acharya, S.S. and N.L. Agarwal. (2012). Agricultural Marketing in India. $5^{\text {th }}$ ed. Oxford \& IBH Publishing Co. Private Limited, New Delhi.

Arunkumar and Rachana Sharma. (2000). Principles of Business Management: Atlantic Publishers and Distributors, New Delhi.

FAO Report. (2009). Asia pacific Forestry sector outlook study II. Indian Forestry Outlook (IFO), Ministry of Environment and Forests, Government of India.

Ivaneevich, Donnely and Gibson. (1991). Principles and Functions of Business Management, Richard D.Irwin USA: Home Wood, Illinious Inc, pp:81.

Katila, M and Paivo Rithinen. (1990). Modeling Newsprint Consumption: A Finnish case study for the period 1960-1986. Acta Forestalia. pp: 217.

Kulkarni, H. D. (2008). Private Farmer and Private Industry Partnerships for Industrial Wood Production: A case study. International Forestry Review. 10. p. 147-155.

Kulkarni, H.D. (2012). Indian Paper Mills Wood Requirement and Generation. ITC limited Paper Boards and Speciality Paper Division, Andra Pradesh, India.

Mohammad A.K. (2012). Management of Paper Industries in India: Prospects and Problems. International Journal of Business Management and Research. 2 (3): p. 54-62.

Philip K. and Kevin L.K. (2005). Marketing Management: Prentice-Hall of India Private Limited. New Delhi.

Sakthimurugan. (2004) Management Principles and Practices: New age International publishers. New Delhi.

Saxena, J.P. (2009). Production and Operation Management, Tata McGraw Hills Education Private Limited, New Delhi.

Subba R.., Ram R. S,P, Sastry N.T.V., and I.B. Devi. (2008). Agricultural Economics: Oxford\& IBH Publishing Co. Private Limited, New Delhi. 